\title{
GOPC/ROS1 Fusion Protein
}

National Cancer Institute

\section{Source}

National Cancer Institute. GOPC/ROS1 Fusion Protein. NCI Thesaurus. Code C99720.

A fusion protein $(878, \sim 109 \mathrm{kDa}$ ) encoded by the GOPC/ROS1 fusion gene. This protein is comprised of most of the Golgi-associated PDZ and coiled-coil motif-containing protein, including the coiled-coil and PDZ domains, fused to almost the entire C-terminal cytoplasmic domain of the proto-oncogene tyrosine-protein kinase ROS protein, including the protein kinase domain. 